\title{
Asian rickets and osteomalacia: patterns of parathyroid response in vitamin $\mathrm{D}$ deficiency
}

By S. W. Stanbury, P. Torkington, G. A. Lumb, P. H. Adams, Preenie de Silva and Carol M. Taylor, Departments of Medicine and Metabolism, The Royal Infirmary, Manchester $M_{13} 9 W L$

We have seen personally more than roo cases of rickets and osteomalacia in Asian immigrant patients during the past 6-8 years and we are satisfied that they arise simply on a basis of vitamin $\mathrm{D}$ deficiency. The present report is concerned principally with a more detailed study of thirty-one patients, aged i I-54 years.

Our patients have been adult women, often pregnant at the time of diagnosis, and adolescents of both sexes. Clinically affected men are rare and a limited population survey showed little biochemical evidence of vitamin D deficiency in the adult male (Holmes, Enoch, Taylor \& Jones, 1973). The calculated dietary intake of vitamin $D$ in this immigrant population is low, but not necessarily less than that of the indigenous Caucasian population (Holmes et al. 1973) and the sexual difference in the incidence of overt bone disease cannot be explained on a dietary basis. It is considered illogical to invoke a widespread deleterious genetical abnormality in one of the world's major populations and, in fact, there is no evidence of abnormal vitamin $D$ metabolism in these individuals: they have a normal capacity to 25- and $1 \alpha$-hydroxylate cholecalciferol (Mawer, 1974). From our clinical experience and from a limited epidemiological survey in the Punjab area of India (Hodgkin, Hine, Kay, Lumb \& Stanbury, 1973) we are convinced that we are dealing with privational deficiency which we believe is caused primarily by inadequate exposure to sunshine. Wilson \& Widdowson (1942) concluded that the development of vitamin D deficiency in India was due to lack of sunshine in a population group with a negligible dietary intake of vitamin D; they considered the high dietary intake of phytate to be irrelevant to the issue. Our limited experience of a cereal-eating group in the Punjab (Hodgkin et al. 1973) agrees with both conclusions. The latter suggestion is also supported by the fact that the vitamin D deficiency can be corrected, in British Asians following their normal social and dietary customs, by as little as i I $\mu \mathrm{g}$ ergocalciferol/d.

Clinical experiences with these patients included the diagnosis of foetal (Russell \& Hill, 1974) and neonatal rickets, and increased intracranial pressure, associated with a serum calcium concentration of $1.25 \mathrm{mmol} / 1$, in a child of 7 months. But most patients had the commonplace classical features of rickets or osteomalacia of varying severity, and several presented with tetany. There are, however, certain features requiring particular comment. 


\section{The extent of vitamin $D$ deficiency}

There are several grounds for suspicion that the deficiency in some of these Asian patients may be marginal, and that they may oscillate between phases of physiological deficiency and of partial repletion. (1) Even in patients with clinically florid rickets, radiography may show evidence of spontaneous healing. (2) In a majority of bone biopsies, tetracycline is bound at the calcification front. (3) Patients equilibrated for 7-10 d on a metabolic balance diet may be found to be in progressively positive mineral balance. (4) Gross biochemical abnormalities in the serum may show partial spontaneous correction during a short period of investigation in hospital.

Furthermore, we do not find that the serum 25-hydroxy-vitamin D (25-OHD) is 'unmeasurable', as has been reported by others. In a group of twelve Asians with overt bone disease, the mean serum 25 -OHD was 3.4 (SD 0.7 ) $\mu \mathrm{g} / 1$; a similar value of $3.6(\mathrm{SD} \mathrm{I.4)} \mu \mathrm{g} / \mathrm{l}$ was found in a group of Caucasians with osteomalacia of differing aetiology. These values contrast with a summer mean of 27 (SD 15.1) $\mu \mathrm{g} / 1$ and winter nadir of 15.8 (SD 6.1) $\mu \mathrm{g} / \mathrm{l}$ in a group of eighteen departmental staff; but such 'house standards' are derived from a privileged population getting much more than average solar exposure. Probably more representative of the local population is a mean value of about $8 \mu \mathrm{g} / \mathrm{l}$ in a random group of pregnant Caucasians, and in a group of our patients with primary hyperparathyroidism.

\section{The time course of healing of overt bone disease}

It is not possible to equate a particular serum concentration of $25-\mathrm{OHD}$ with the presence of osteomalacia. A few days treatment with $22.5 \mu \mathrm{g}$ ergocalciferol/d may bring the serum $25-\mathrm{OHD}$ into the lower part of the range encountered in healthy individuals (see above) but it will produce no detectable clinical or radiographic change. Indeed, a repeated bone biopsy after I year of continued treatment may show that the bone is still abnormal.

Serious misconceptions regarding response to treatment, requirement for vitamin $\mathrm{D}$ and supposed resistance to the vitamin can arise if a single index is used as a measure of healing. The change of serum alkaline phosphatase (EC 3.1.3.1) in relation to the duration of treatment in ten patients is shown in Fig. 1. Serum alkaline phosphatase activity decays as a multiple exponential function of time; but, if all values obtained in the first year are treated as a single exponential function, the mean half-time of the decay is $280 \mathrm{~d}$. Thus a high serum alkaline phosphatase level after weeks or months of treatment is not evidence of lack of response (an appropriate response can often be demonstrated unequivocally by radiography), nor is it evidence of 'vitamin D resistance'. It is not an indication for additional vitamin $\mathrm{D}$ but for patience; complete healing of the bone disease of vitamin $\mathrm{D}$ deficiency may be a lengthy process. 


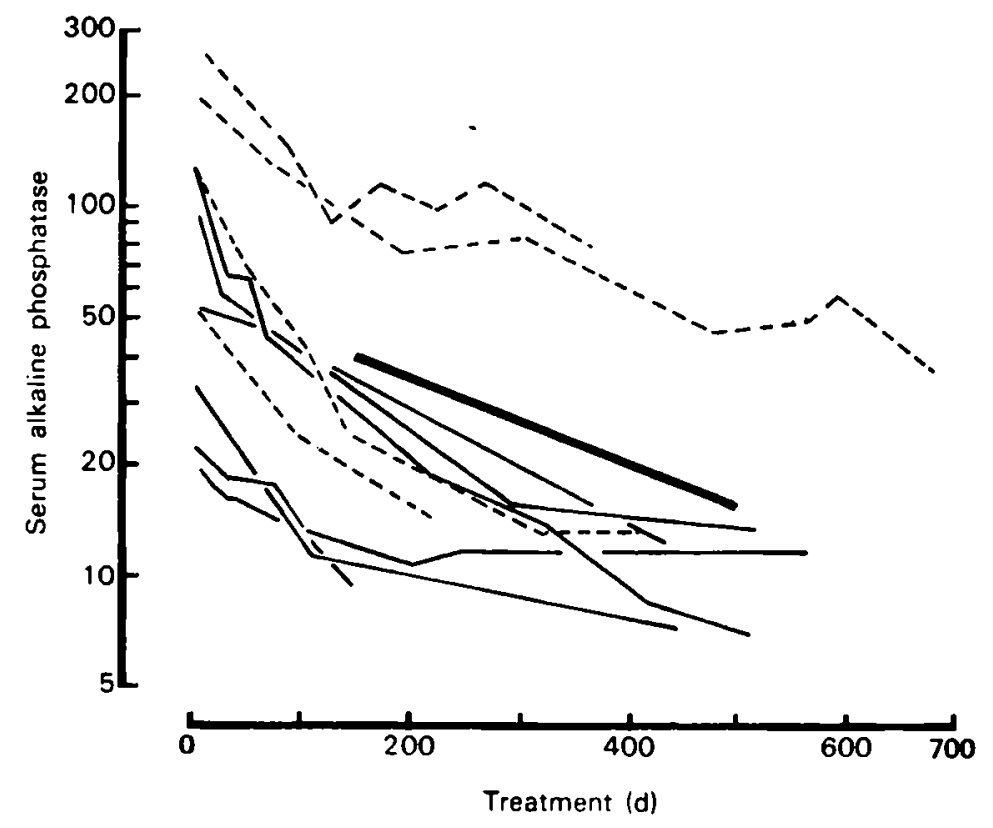

Fig. I. Changes in serum alkaline phosphatase (EC 3.1.3.1) level (King-Armstrong units; King \& Armstrong, 1934) with ergocalciferol treatment in four cases of rickets $(--\infty)$ and six cases of osteomalacia (—, mean decrease during the first year.

\section{Vitamin $D$ deficiency and parathyroid function}

The serum concentrations of $\mathrm{Ca}$ and phosphorus in these Asian patients varied widely and an attempt has been made to relate these changes to the prevailing state of parathyroid function.

Because of the physiological changes in serum $\mathrm{P}$ and alkaline phosphatase with age, it is not strictly permissible to treat our cases as a single population. Values of serum alkaline phosphatase (13-220 King-Armstrong units (King \& Armstrong, 1934)) were distributed normally, whereas the values of both serum $P(0.65-2.33$ $\mathrm{mmol} / \mathrm{l})$ and serum $\mathrm{Ca}\left(\mathrm{I} \cdot 35^{-2} \cdot 85 \mathrm{mmol} / \mathrm{l}\right)$ were distributed bimodally. The bimodality of the serum $P$ was not simply a function of age but was determined by a distinct subgroup (group 2, seven patients) of adolescent males with a tendency to hyperphosphataemia (1.39-2.33 mmol P/l): the bimodality of the serum Ca values was determined by two middle-aged women (group 3 ) with moderate hypercalcaemia $(2.65$ and $2.78 \mathrm{mmol} \mathrm{Ca} / \mathrm{l})$.

The majority of patients (group 1 , twenty-two patients) had the changes classically associated with vitamin $\mathrm{D}$ deficiency: moderate hypocalcaemia (mean $2.02(\mathrm{SD} 0.2) \mathrm{mmol} \mathrm{Ca} / \mathrm{l}$ ) and a tendency to hypophosphataemia (mean 0.82 (SD $0 \cdot 14) \mathrm{mmol} \mathrm{P} / \mathrm{l})$. These patients had variably severe radiographic signs and histological changes of hyperparathyroidism and the serum immunoreactive parathyroid hormone (IPTH) was raised (mean 2.25 (SD 2.4) $\mu \mathrm{g} / \mathrm{l}$ ) to the levels 
commonly measured in primary hyperparathyroidism (normal range $0-0.8 \mu \mathrm{g} / 1$; mean $0.35(\mathrm{SD} 0.3) \mu \mathrm{g} / \mathrm{l})$. On treatment with vitamin $\mathrm{D}$, the serum IPTH diminished progressively, roughly in parallel with the change in serum alkaline phosphatase and reciprocally with serum $\mathrm{Ca}$, and the radiographic signs of hyperparathyroidism healed.

In some patients of group I, the serum IPTH was very high $(3-8 \mu \mathrm{g} / \mathrm{l})$ and the signs of hyperparathyroidism were extremely severe. The two women of group 3 , with serum IPTH of $8 \mu \mathrm{g} / \mathrm{l}$, would have been classified in group 1 as osteomalacia with very severe osteitis fibrosa but for their having moderate but definite hypercalcaemia. The initial response to treatment with ergocalciferol in these two patients has been reported previously (Lumb \& Stanbury, 1974): the course over an extended period of 2 years is shown in Fig. 2. One patient took her treatment assiduously and maintained adequate levels of serum 25-OHD. Her serum alkaline phosphatase and IPTH levels fell exponentially throughout the 2 years, at the end of which the alkaline phosphatase level was normal. She was then still moderately hypercalcaemic and, although the serum IPTH had fallen to $12.5 \%$ of its initial value, it was still three times the normal average. The initial response in the second patient was identical but it is known that she defaulted from treatment and, after $300 \mathrm{~d}$, the serum $25-\mathrm{OHD}$ was no higher than $4 \cdot 1 \mu \mathrm{g} / \mathrm{l}$. Her condition relapsed, with rises in both serum alkaline phosphatase and IPTH and a recurrence of radiographic signs, even although she remained hypercalcaemic.

The observed 8-fold change in serum IPTH occurred despite the persistence of hypercalcaemia; and the serum levels of $\mathrm{Ca}$ and IPTH were not significantly correlated during the 2 years. It appears that treatment with ergocalciferol has caused a slow, long-term suppression of parathyroid secretion, which may be independent of change in serum $\mathrm{Ca}$ but which is accompanied by healing of the hyperparathyroid component of the bone disease (Lumb \& Stanbury, 1974). It is suggested that this phenomenon is analogous to the very slow decay of the hypercalcaemia, due to parathyroid hyperplasia, seen in some patients with renal failure treated successfully by renal transplantation; and that it reflects structural involution of parathyroid hyperplasia, and is produced in some way by a direct action of the relevant vitamin D sterol on the parathyroid glands.

The long-term nature of this effect of vitamin $\mathrm{D}$ treatment is emphasized by comparison with the acute effects of $\mathrm{Ca}$ infusion in these two hypercalcaemic patients (Lumb \& Stanbury, 1974). As was also the general situation in patients of group I, a rapid elevation of the serum Ca by less than $0.25 \mathrm{mmol} / 1$ produced an apparent arrest of parathyroid secretion; serum IPTH decayed with a half-time of 10-15 min and, within $15-30 \mathrm{~min}$, the level had fallen to $20 \%$ or less of its initial value (Fig. 3). Thus a trivial, sharp rise in serum Ca had apparently produced almost instantaneously the same functional effect as 2 years' treatment with ergocalciferol. This in itself makes it unlikely that the effects on serum IPTH shown in Fig. 2 were induced through change in serum Ca. One is obviously concerned with two distinct phenomena of parathyroid function.

The hypocalcaemic, hyperphosphataemic patients of group 2 illustrate two other 

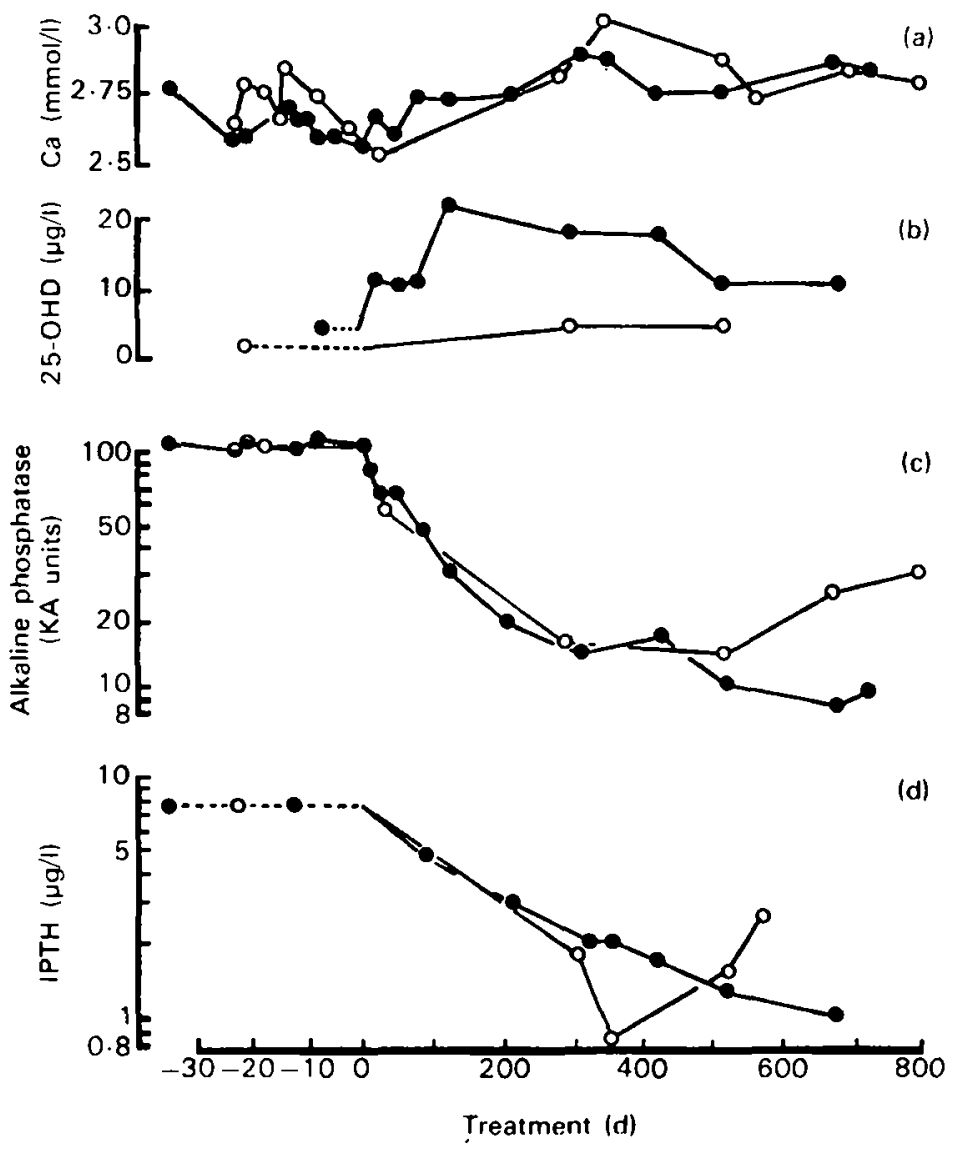

Fig. 2. Effects of treatment with ergocalciferol in two osteomalacic patients with hypercalcaemia: $0-56 \mu \mathrm{g}$ ergocalciferol/d, treatment maintained; $\bigcirc-0,22.5 \mu \mathrm{g} \mathrm{ergocalciferol} / \mathrm{d}$, patient defaulted. (a) Serum calcium levels; (b) serum 25-hydroxy-vitamin D (25-OHD) levels; (c) serum alkaline phosphatase (EC 3.1.3.1) levels (King-Armstrong (KA) units; King \& Armstrong, 1934); (d) serum immunoreactive parathyroid hormone (IPTH) levels (estimated with bovine PTH). The question of whether these patients had primary hyperparathyroidism, complicated by vitamin $\mathrm{D}$ deficiency, or hypercalcaemic secondary hyperparathyroidism, resulting from chronic vitamin D deficiency, is discussed by Lumb \& Stanbury (1974).

facets of parathyroid function. These patients were male adolescents, aged II-1 7 years, apparently undergoing a phase of relatively rapid growth. They were profoundly hypocalcaemic $\left(1 \cdot 35^{-1} \cdot 70 \mathrm{mmol} \mathrm{Ca} / \mathrm{l}\right)$ with serum $P$ between $\mathrm{I} \cdot 5$ and $2.3 \mathrm{mmol} / 1$; their bone disease was not severe and the serum IPTH (mean I 46 (SD $0.6) \mu \mathrm{g} / \mathrm{l} ; n=4$ ), although increased, was relatively low for the extent of hypocalcaemia. Infusion of parathyroid extract produced a significant increment in serum Ca but had no phosphaturic effect on the kidney. These patients were thus examples of acquired 'pseudohypoparathyroidism'. Treatment with vitamin D corrected the hypocalcaemia and reduced serum IPTH, but it simultaneously 


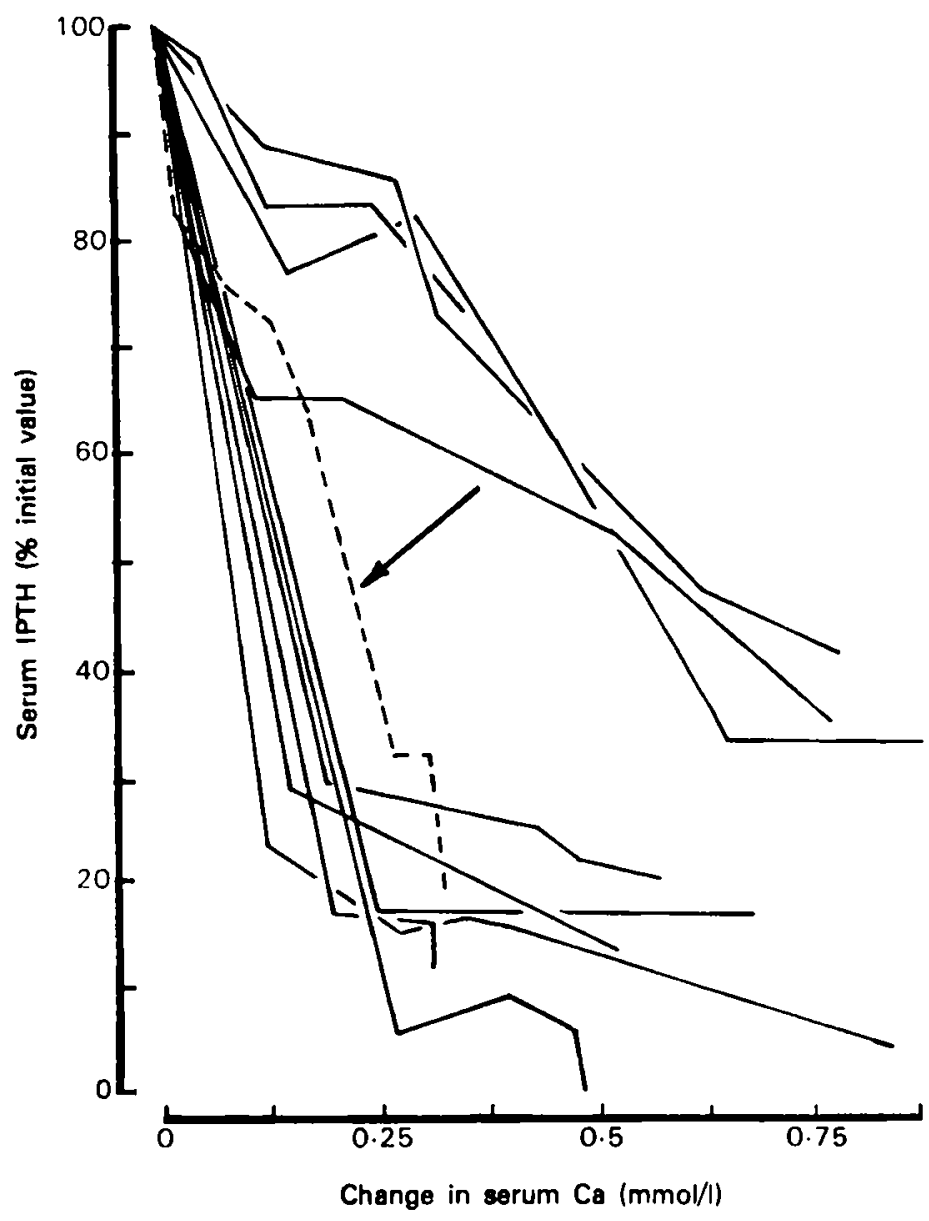

Fig. 3. Response of serum immunoreactive parathyroid hormone (IPTH) to calcium infusion in osteomalacic patients of groups $\mathrm{I}$ and 3 ('normocalcaemic': serum $\mathrm{Ca} 2 \cdot 02-2 \cdot 78 \mathrm{mmol} / \mathrm{l}$, serum IPTH $2.4-8.0 \mu \mathrm{g} / \mathrm{l}$ ) (lower left group) and of group 2 (hypocalcaemic: serum $\mathrm{Ca} 1 \cdot 35-1 \cdot 70 \mathrm{mmol} / \mathrm{h}$, serum IPTH $1 \cdot 1-1 \cdot 6 \mu \mathrm{g} / \mathrm{l}$ ) (upper right group). The arrow connects the responses during and following (- - ) the infusion in one patient of group 2.

corrected the hyperphosphataemia, serum $\mathrm{Ca}$ and $\mathrm{P}$ levels during treatment being related inversely.

Appropriately for hypocalcaemic patients, and in contrast with the behaviour of patients in groups $\mathrm{I}$ and 3 , infusion of $\mathrm{Ca}$ did not produce immediate suppression of parathyroid secretion (Fig. 3). With continued infusion to normocalcaemic levels, the serum IPTH diminished in proportion with the increment in serum Ca; regression analysis indicates a zero value of serum IPTH with a serum $\mathrm{Ca}$ level just above $2.75 \mathrm{mmol} / \mathrm{l}$. This pattern of proportionate response is the same as was demonstrated in classical studies in the cow but it differs qualitatively from the two patterns of parathyroid response already discussed. Continuation of 
measurements after termination of the $\mathrm{Ca}$ infusion, in these 'pseudohypoparathyroid' and other hypocalcaemic patients, uncovered what appears to be a fourth pattern of parathyroid response. Commonly, only a single blood sample was obtained at a variable time after stopping infusion and, in this, the serum IPTH was inappropriately high for the then prevailing serum $\mathrm{Ca}$ level (and sometimes appreciably higher than any value recorded previously in that individual). A deliberate study of this recovery phase, with serial blood sampling, showed that the regression of serum IPTH $v$. serum $\mathrm{Ca}$ was now much steeper (Fig. 3); that is, a given change in serum $\mathrm{Ca}$ was associated with a greater change in serum IPTH during the recovery phase than during the initial infusion. Thus, the temporary restoration of a normal serum $\mathrm{Ca}$ level appeared to induce in the parathyroid gland a greater capacity to deliver its hormone into the blood.

The nature of these various responses of the parathyroid glands, and their relation to the development of hypercalcaemia and 'pseudohypoparathyroidism' will be discussed elsewhere. The patterns of parathyroid response, and the accompanying changes in the bone, resemble those described previously in the conditioned I,25-dihydroxycholecalciferol deficiency of renal failure (Stanbury \& Lumb, I966); but they occur in the absence of glomerular impairment and renal retention of phosphate.

These studies were supported by a grant to S.W.S. from the Medical Research Council.

\section{REFERENCES}

Hodgkin, P., Hine, P. M., Kay, G. H., Lumb, G. A. \& Stanbury, S. W. (1973). Lancet ii, 167. Holmes, A. M., Enoch, B. A., Taylor, G. A. \& Jones, M. E. (1973). Q. $Y l$ Med. 42, 125.

King, E. J. \& Armstrong, A. R. (1934). Can. med. Ass. J. 31, 376.

Lumb, G. A. \& Stanbury, S. W. (1974). Am. J. Med. 56, 833.

Mawer, E. B. (1974). In The Metabolism and Function of Vitamin D, p. 27 [D. R. Fraser, editor]. London: The Biochemical Society.

Russell, J. G. B. \& Hill, L. F. (1974). Br. F. Radiol. 47, $73^{2}$.

Stanbury, S. W. \& Lumb, G. A. (1966). Q. $y_{l}$ Med. 35, 1.

Wilson, D. C. \& Widdowson, E. M. (1942). Indian $\mathcal{~}$. med. Res. Mem. no. 34. 